\title{
Effects of catecholamines on secretion of adrenocorticotrophic hormone (ACTH) in man
}

\author{
S AL-DAMLUJI, L H REES \\ From the Department of Endocrinology, St Bartholomew's Hospital, London
}

SUMMARY The hypothalamus receives a rich supply of adrenergic and noradrenergic nerve fibres from the brain stem, terminating in many hypothalamic regions, including the paraventricular nucleus, which is the site of the cell bodies of corticotrophin releasing factor (CRF) neurones in man. Experimental evidence has shown that an $\alpha_{1}$ adrenoceptor mechanism stimulates adrenocorticotrophic hormone (ACTH) secretion in man. The site of action of this mechanism seems to be within the blood brain barrier, presumably modulating the secretion of the CRF complex. This mechanism is important in the control of ACTH secretion in some physiological conditions in healthy subjects.

The pioneering work of Harris $^{1}$ postulated the existence of a hypothalamic corticotrophin releasing factor (CRF) that is transported in the hypothalamohypophyseal portal system to the anterior pituitary gland, and which stimulates the secretion of adrenocorticotrophic hormone (ACTH). This work was crowned by Vale et al, who isolated and synthesised ${ }^{2}$ a 41 amino acid peptide from ovine hypothalami with specific CRF bioactivity. Equivalent peptides have been identified in other species, including man. Immunohistochemical studies have shown this peptide to be widely distributed in the central nervous system, but within the hypothalamus it is localised mostly in the parvocellular neurones of the paraventricular nucleus. The axons extend to the zona externa of the median eminence, which is the site of the first capillary bed in the hypothalamohypophyseal portal system. ${ }^{3-5}$

Further investigations have shown that other peptides may possess CRF activity. Prominent among these is vasopressin, which has a weak direct stimulant effect on ACTH secretion; but more importantly, it strongly enhances the activity of CRF-41. ${ }^{6}$ It therefore seems that the hypothalamus secretes a CRF "complex" the constituents of which may vary under different circumstances. The paraventricular nucleus contains high concentrations of catecholamines which may influence the activity of the hypothalamopituitary adrenal axis (HPAA). In theory peripheral circulating catecholamines may also influence ACTH secretion as activation of the sympathoadrenal system often accompanies that of the HPAA.

In this review, we summarise the relation of catecholamine systems to the hypothalamus and the pituitary gland and discuss the evidence from human experiments for a regulatory role of these amines in ACTH secretion.

\section{Catecholamine systems, the hypothalamus, and the pituitary gland}

The hypothalamus contains the highest concentrations of noradrenaline in the brain. ${ }^{7-9}$ The origin of this noradrenaline is almost all extrinsic as surgical isolation of the hypothalamus results in a drastic reduction of its noradrenaline content. ${ }^{1011}$ The noradrenergic innervation of the hypothalamus is derived from parts of the reticular formation in the ventral and dorsal medulla oblongata and the locus ceruleus at the junction of the pons and the midbrain. The axons ascend in the medial forebrain bundle, and some cross the midline. ${ }^{12-16}$ Noradrenergic nerve terminals can be identified in every hypothalamic nucleus, but two of the most densely innervated are the paraventricular and supraoptic nuclei ${ }^{121417}$ and the median eminence. ${ }^{1417-19}$ The noradrenergic innervation of the paraventricular nucleus is derived largely from the ventral medulla. ${ }^{21}$ By simultaneously using catecholamine histofluorescence and neuropeptide immunocytochemistry, catecholaminergic neurones were observed with their terminals on the cell bodies of peptidergic neurones in hypothalamic nuclei, ${ }^{2022}$ suggesting a monosynaptic contact. 
The hypothalamus also contains high concentrations of adrenaline. ${ }^{7}$ The cell bodies of adrenergic neurones lie within the reticular formation in the upper medulla ${ }^{2324}$ and project to various parts of the brain, including the diencephalon, in which the highest concentrations are found in the paraventricular and arcuate nuclei and the median eminence. ${ }^{23-27}$ Using combined immunocytochemistry Mezey et $a l^{28}$ showed that adrenergic neurones lie in close proximity to CRF-41 cell bodies in the paraventricular nucleus of rats.

The dopaminergic innervation of the hypothalamus is almost all intrinsic; surgical isolation of the hypothalamus results in little reduction of dopamine content. ${ }^{1011}$ In the hypothalamus the tuberoinfundibular dopaminergic tract has its cell bodies in the arcuate nucleus, near the inferior end of the third ventricle. The axons project to the zona externa of the median eminence where they are in close proximity to the first capillary bed of the hypothalamo-hypophyseal portal system, into which dopamine is secreted. Dopaminergic neurones also supply the neural and the intermediate lobes of the rat pituitary. ${ }^{1218}$ The incerto-hypothalamic tract has its cell bodies mainly in the zona incerta and partly innervates the paraventricular nucleus. ${ }^{29}$

The mammalian adenohypophysis does not receive a catecholaminergic innervation. ${ }^{3031}$ The neural and intermediate lobes of the rat contain considerable quantities of dopamine and smaller amounts of noradrenaline. $^{30}$ The dopaminergic innervation is derived from neurones with their cell bodies in the arcuate nucleus, ${ }^{32}$ but the noradrenergic innervation seems to be from peripheral sympathetic nerves accompanying blood vessels. ${ }^{32}$

Dopamine is secreted into hypophyseal portal plasma, ${ }^{33}$ and its role in the tonic inhibition of prolactin secretion is well established. There is controversy, however, as to whether adrenaline and noradrenaline are secreted into hypophyseal portal plasma. Several studies in rats have reported the concentrations of adrenaline and noradrenaline in hypophyseal portal plasma to be no greater than those in peripheral plasma. ${ }^{33-37}$ More recently, some investigators ${ }^{38-40}$ have found that the concentration of adrenaline in plasma from the transected pituitary stalk of anaesthetised rats was $60-90 \%$ higher than the adrenaline concentrations in peripheral venous plasma, and interpreted this as indicating a central source of adrenaline secretion into the portal circulation. The source of adrenaline in those experiments may have been partly derived from the severed stalk nerves containing adrenergic fibres innervating the posterior and intermediate lobes, as the concentration of adrenaline in plasma from a single portal vessel in the intact stalk is lower than that in peripheral plasma. ${ }^{37}$ Nevertheless, whichever of these views concerning the rat prevails, as the mammalian adenohypophysis does not receive a catecholaminergic innervation ${ }^{3132}$ it is unlikely that the anterior pituitary is exposed to much higher concentrations of adrenaline than those found in peripheral plasma.

The distribution of adrenoceptors in the hypothalamus has been studied using autoradiography and radioligand binding studies on homogenised rat brain membranes. Within the hypothalamus, $\alpha_{1}$ and $\alpha_{2}$ adrenoceptors are found in several nuclei, including the paraventricular nucleus. ${ }^{41}$ The median eminence has a high density of $\alpha_{2}$ adrenoceptors but no high $\alpha_{1}$ binding. ${ }^{41}$ The density of $\beta$-adrenoceptor binding sites is lower in the hypothalamus than in the cerebral cortex, and even lower densities are found in the adenohypophysis, about $10 \%$ of the density in the cortex. ${ }^{42}$ Roughly equal densities of the two $\beta$-adrenoceptor subtypes are found in the hypothalamus, but only $\beta_{2}$ adrenoceptors are found in the rat adenohypophysis. ${ }^{42}$ The paraventricular nucleus has an intermediate density of $\beta$-adrenoceptor binding sites. ${ }^{41}$ Within the hypothalamus dopaminergic receptors are found in highest densities in the median eminence (mostly D-1 subtype), but the paraventricular nucleus has an intermediate density of both D-1 and D-2 binding sites. ${ }^{41}$ In the adenohypophysis only the D-2 receptor subtype is found and helps to regulate prolactin secretion. ${ }^{43}$

\section{Effects of adrenoceptor stimulation on ACTH secretion}

The early studies that assessed the interaction of catecholamines and the HPAA in man examined the effects of administration of adrenaline on various indirect indices of HPAA activity, such as the blood eosinophil count, ${ }^{44-46}$ 17-hydroxycorticosteroids, ${ }^{45-48}$ and various early ACTH bioassays, ${ }^{4950}$ but the results were conflicting. More recently, intravenous infusions of adrenaline $e^{5152}$ and noradrenaline ${ }^{5354}$ have been reported to have no stimulatory effect on basal plasma cortisol concentrations in man. Muller-Hess et $\mathbf{a l}^{51}$ suggested that adrenaline may attenuate the cortisol response to hypoglycaemia induced by insulin, but this is probably attributable to the attenuation of the hypoglycaemic effect of insulin by adrenaline. Other evidence from man includes the observations that amphetamines stimulate the secretion of ACTH and cortisol and that the effect is blocked by thymoxamine but not propranolol, which suggests that it is mediated by $\alpha_{1}$ adrenoceptors. ${ }^{55} 56$ Amphetamines have complex pharmacological actions and cause a generalised arousal effect that is correlated with the height of the cortisol peak, ${ }^{5557}$ so the mechanism by which they stimulate ACTH secretion is uncertain. 
In our current investigations of $\alpha$-adrenergic agonists we have chosen methoxamine, a highly selective agonist at post-synaptic $\alpha_{1}$ adrenoceptors ${ }^{58} 59$ that is free of behavioural arousal effects when injected intracerebroventricularly in experimental animals. ${ }^{60}$ Like Nakai et $a l,{ }^{61}$ we found that intravenous infusions of methoxamine stimulate the secretion of ACTH and cortisol in man (fig 1). ${ }^{62}$ The stimulant effects of methoxamine on ACTH and cortisol secretion were dose dependent and were accompanied by an increase in blood pressure, as may be expected from an $\alpha_{1}$ adrenoceptor agonist. ${ }^{62}$ The effects of methoxamine were abolished by concomitant administration of the highly selective $\alpha_{1}$ adrenoceptor antagonist thymoxamine, ${ }^{59}$ confirming that they were mediated by $\alpha_{1}$ adrenoceptors (fig 1). ${ }^{62}$ When given in large doses in experimental animals, methoxamine may have $\beta$-adrenoceptor antagonist activity, ${ }^{63}$ but this is not the mechanism by which it stimulates the HPAA in man: the effect was abolished by concomitant administration of thymoxamine, which lacks activity at $\beta$-adrenoceptors. ${ }^{64}$ Thymoxamine has weak $\mathrm{H}-1$ antihistaminic action on the guinea pig ileum in vitro, ${ }^{64}$ but we have found that thymoxamine does not attenuate the bronchoconstrictor action of intravenously injected histamine, ${ }^{65}$ suggesting that thymoxamine has no $\mathrm{H}-1$ antihistaminic activity in the doses used in man.

To examine whether methoxamine stimulates ACTH secretion by a central effect or by a peripheral action, such as vasoconstriction or an increase in blood pressure, we compared the effects of methoxamine to those of the more hydrophilic noradrenaline. ${ }^{66}$ Noradrenaline is a potent $\alpha_{1}$ adrenoceptor agonist ${ }^{58}$ that reaches the pituitary gland and the median eminence after a systemic injection but does not cross the blood brain barrier. ${ }^{67-69}$ The noradrenaline infusions were designed to raise systolic blood pressure by amounts equivalent to those produced by methoxamine, so that equivalent peripheral $\alpha_{1}$ adrenoceptor activation by the two drugs could be compared. ${ }^{62}$ Fig 2 shows that the noradrenaline infusions were not followed by a rise in plasma cortisol above the mean control value, suggesting that the stimulation of the HPAA by methoxamine is exerted by a central rather than a peripheral mechanism. As the pituitary gland and the median eminence are outside the blood brain barrier and are accessible to circulating noradrenaline, ${ }^{67-69}$ our inability to stimulate the HPAA with noradrenaline suggests that the site of the stimulant $\alpha_{1}$ adrenoceptors is within the blood brain barrier, presumably modulating the secretion of the CRF complex.

In addition to its hydrophilic properties, noradrenaline differs from methoxamine in its $\beta$ and $\alpha_{2}$ adrenoceptor agonist actions. These receptor activities of noradrenaline, however, do not account for the differences from methoxamine, as we found that $\beta_{1}$ and $\beta_{2}$ adrenoceptor agonists (prenalterol and salbutamol, respectively), do not have a direct action on ACTH secretion in man; and an $\alpha_{2}$ antagonist (yohimbine) does not modify cortisol secretion during noradrenaline infusions. ${ }^{62}$

The noradrenaline infusions caused a slight inhibition of cortisol secretion compared with saline (fig 2), ${ }^{62}$ as had been described by Wilcox et al. ${ }^{53}$ The mechanism of this inhibitory effect of peripheral
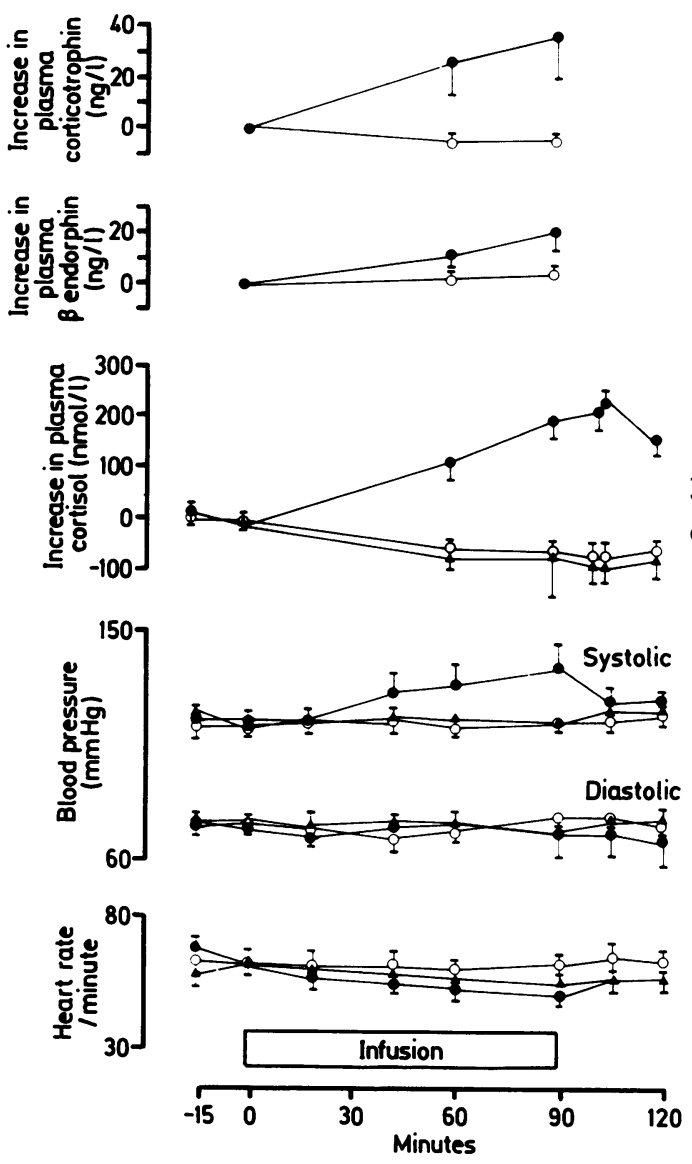

Fig 1 Effects of infusions of saline and methoxamine $(0.22 \mathrm{mg} / \mathrm{minute})$ with and without thymoxamine $(0.2 \mathrm{mg} / \mathrm{kg}$ bolus $+2 \cdot 2 \mu \mathrm{g} / \mathrm{kg} /$ minute) on plasma $A C T H$, immunoreactive $\beta$ endorphin (C-terminal $L P H)$, cortisol, heart rate $(H R)$, and blood pressure $(B P)$ in nine normal subjects. Open circles, saline; closed circles, methoxamine; triangles, methoxamine and thymoxamine. (Reproduced by permission of the publishers of Neuroendocrinology, SKarger AG, Basel.) 


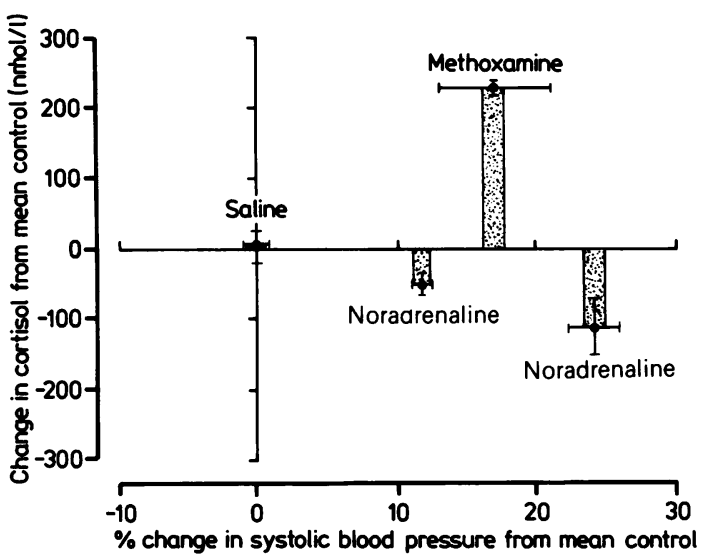

Fig 2 Comparison of effects of methoxamine and noradrenaline on plasma cortisol and systolic blood pressure (expressed as percentage change from mean control $\pm S E M)$. Noradrenaline infusions were given to increase $\overline{S B P}$ by about 10 and $25 \%$ of the mean control value, similar to changes after methoxamine. (Reproduced by permission of the publishers of Neuroendocrinology, S Karger AG, Basel.)

adrenoceptor activation on the HPAA is unclear, but it may be caused by the known inhibitory effect of intravenous infusions of noradrenaline on the secretion of vasopressin, ${ }^{70}$ which is a constituent of the CRF complex.

In another experiment a different approach was used to examine the site of action of $\alpha_{1}$ adrenoceptors in stimulating ACTH secretion. We studied a group of patients with hypopituitarism caused by diseases of the hypothalamus or the pituitary stalk, such as craniopharyngiomas. These patients respond to an intravenous injection of synthetic ovine CRF -41 by an increase in ACTH and cortisol secretion but they do not respond to hypoglycaemia induced by insulin with a rise in plasma cortisol. This indicates that the cause of their hypoadrenalism is a failure of the synthesis or delivery of CRF, rather than a primary defect in ACTH reserve. If the site of action of the stimulant $\alpha_{1}$ adrenoceptors in stimulating ACTH secretion is on the hypothalamus or its central connections - that is, within the blood barrier-then these patients would be expected to have no ACTH or cortisol response to an infusion of methoxamine. Fig 3 shows the result of a study in one such patient who shows no cortisol response to hypoglycaemia induced by insulin or methoxamine but responds normally to synthetic ovine CRF-41. This is consistent with the view that the site of action of the stimulant $\alpha_{1}$ adrenoceptors is likely to be on the hypothalamus or its central connections, rather than directly on the pituitary gland.

Some data from experimental animals are consis- tent with the view that central adrenergic mechanisms stimulate the HPAA. Thus in cats corticosteroid secretion is stimulated by the implantation of noradrenaline into hypothalamic areas but not into the pituitary gland. ${ }^{71}$ In rats the depletion of hypothalamic noradrenaline by stereotaxic injection of the neurotoxin 6-hydroxydopamine into the medial forebrain bundle is followed by a reduction of ACTH secretion. ${ }^{72}$ Other experimental evidence, however, has been collected on the rat and the dog and has been interpreted as showing an inhibitory effect of central $\alpha$ adrenoceptors on ACTH secretion. ${ }^{73}$ The systemic administration of $\beta$-adrenoceptor agonists stimulates ACTH secretion in the rat. ${ }^{74}$ Most of these apparently conflicting data may be explained on the basis of the technical approaches and the pharmacological properties of the compounds used.

Adrenaline has been reported to enhance the stimulant effect of synthetic ovine CRF-41 on ACTH secretion by cultured rat adenohypophyseal cells in vitro. ${ }^{7576} \mathrm{We}$ therefore investigated the effects of increases in plasma concentrations of adrenaline within the normal range on the activity of CRF-41 in man in vivo. ${ }^{77}$ Intravenous infusions of adrenaline that increased plasma adrenaline concentrations to 4.33 (SEM 0.82) nmol/1 had no stimulant effect on ACTH or cortisol secretion basally or after the injection of oCRF-41 (fig 4). The plasma adrenaline concentrations during the adrenaline infusions were at the upper limit of the range that has been observed in normal subjects and patients in a variety of physiological and pathological situations, such as

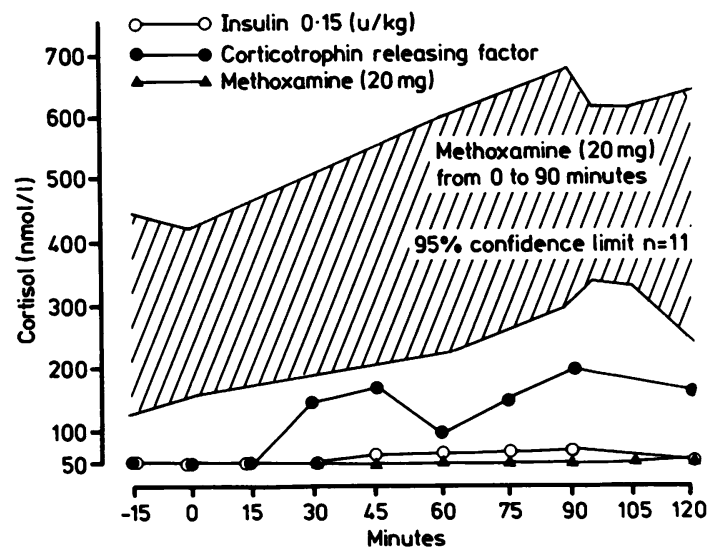

Fig 3 Effects on plasma cortisol of hypoglycaemia induced by insulin (blood glucose nadir $<2.2 \mathrm{mmol} / \mathrm{l}$ ), synthetic ovine CRF-41 (100 $\mu \mathrm{g}$ bolus at 0 minutes), and methoxamine ( $20 \mathrm{mg}$ intravenously from 0 to 90 minutes) in patient with craniopharyngioma causing hypothalamic deficiency. Shaded areas are $95 \%$ confidence limits of plasma cortisol response to identical dose of methoxamine in 11 normal subjects. 


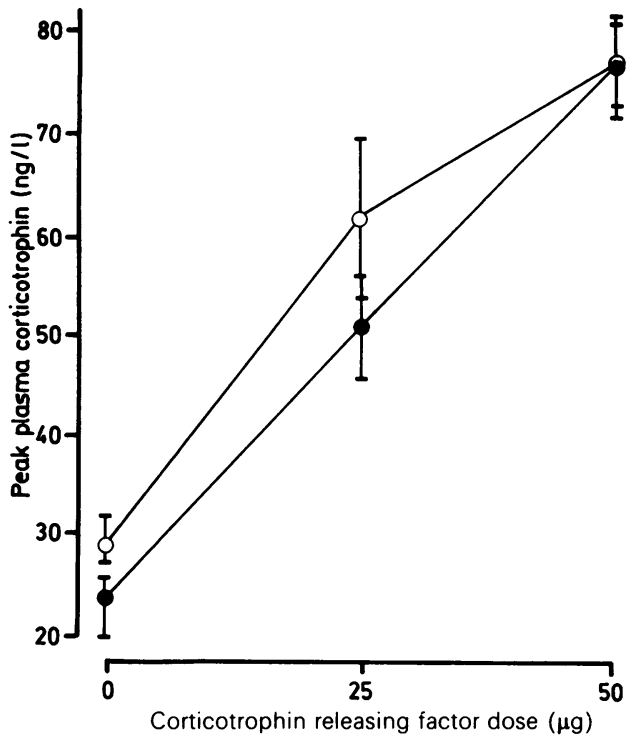

Fig 4 Dose-response relation of plasma ACTH to bolus doses of synthetic ovine CRF-41 during infusions of saline (open circles) and adrenaline ( $3 \mu \mathrm{g} /$ minute, closed circles) in six normal subjects. Mean SEM values are shown.

(Reproduced by permission of the publishers of The Journal of Endocrinology.)

cold exposure, ${ }^{78}$ near maximal exercise, ${ }^{79}$ acute myocardial infarction ${ }^{80}$ in patients in an intensive care unit ${ }^{81}$ and in septicaemic patients who are not shocked. ${ }^{82}$ Higher concentrations of plasma adrenaline are observed only in extremes of pathological situations, such as impending death ${ }^{81}$ or severe septicaemia with shock, ${ }^{82}$ and after the pharmacological stimulus of hypoglycaemia induced by insulin. It was therefore concluded that circulating adrenaline has no physiological role in stimulating ACTH secretion either basally or in the presence of CRF-41. This conclusion is compatible with the previous findings that peripheral adrenergic stimulation with noradrenaline, prenalterol, and salbutamol was not associated with activation of the pituitary adrenal axis. The possibility that hypophyseal portal plasma may contain somewhat higher concentrations of adrenaline derived from a central source is controversial and has been discussed here. Milsom et $a^{83}$ studied the effects of adrenaline, noradrenaline, and clonidine and found no enhancement of the action of synthetic ovine CRF-41 by any of these substances.

In our investigation of the interaction of adrenaline and $\mathrm{CRF}-41$ the adrenaline infusions were associated with a transient inhibition of ACTH secretion basally and a slowing of the rate of rise of ACTH secretion after the injection of CRF-41. ${ }^{77}$ This is compatible with the previously described inhibition of cortisol secretion by noradrenaline described above, and localises the site of action of this effect to the pituitary gland.

The effects of clonidine on the activity of the HPAA have also been examined, with conflicting results: the drug has been reported both to inhibit ${ }^{8485}$ and to have no effect ${ }^{8687}$ on corticotroph activity. This may perhaps be due to the drug's complex pharmacology, as it stimulates both $\alpha_{1}$ and $\alpha_{2}$ adrenoceptors, the latter having the effect of inhibition of noradrenaline release from nerve endings. Clonidine also causes hypotension, which is a potent stimulus to ACTH secretion, ${ }^{8889}$ and sedation, ${ }^{60}$ which would be expected to depress the HPAA.

\section{The physiological importance of the stimulant $\alpha_{1}$ adrenoceptors}

\section{THE ROLE OF $\alpha_{1}$ ADRENOCEPTORS IN DETERMINING THE 24 HOUR CORTISOL SECRETORY PATTER N 90}

A group of normal subjects were given 24 hour intravenous infusions of the $\alpha_{1}$ adrenoceptor agonist methoxamine, the $\alpha_{1}$ antagonist thymoxamine, and saline under double blind conditions. During waking hours, the methoxamine infusion was accompanied by higher concentrations of plasma cortisol than saline, while the converse held with thymoxamine (fig 5). In contrast, the nocturnal surge in cortisol secretion was unaffected by these adrenergic manipulations. The results suggest than an $\alpha_{1}$ adrenoceptor mechanism maintains cortisol secretion during waking hours but not at night. There is evidence from experimental animals that the nocturnal activity of the HPAA may be mediated by serotonergic and cholinergic mechanisms.

\section{THE ROLE OF $\alpha_{1}$ ADRENOCEPTORS IN CORTISOL SECRETION AFTER FOOD}

Food ingestion stimulates cortisol secretion in man by an unknown mechanism. ${ }^{91}$ In rats feeding increases the turnover of noradrenaline in the hypothalamus, ${ }^{92}$ so we investigated the role of $\alpha_{1}$ adrenoceptors in the mediation of cortisol secretion after eating. ${ }^{93}$ A group of normal subjects was given three hour intravenous infusions of saline, methoxamine, and thymoxamine, and a standard meal was eaten 60 minutes after the start of the intravenous infusions. Methoxamine enhanced and thymoxamine attenuated the ACTH and cortisol responses to the meal without affecting nutrient absorption (fig 6). ACTH is found in the gastrointestinal tract as well as in the pituitary gland. ${ }^{9495}$ To determine whether the source of this ACTH secretion is the pituitary gland or the gastrointestinal tract four patients with recent onset of ACTH deficiency and normally responsive adrenal 


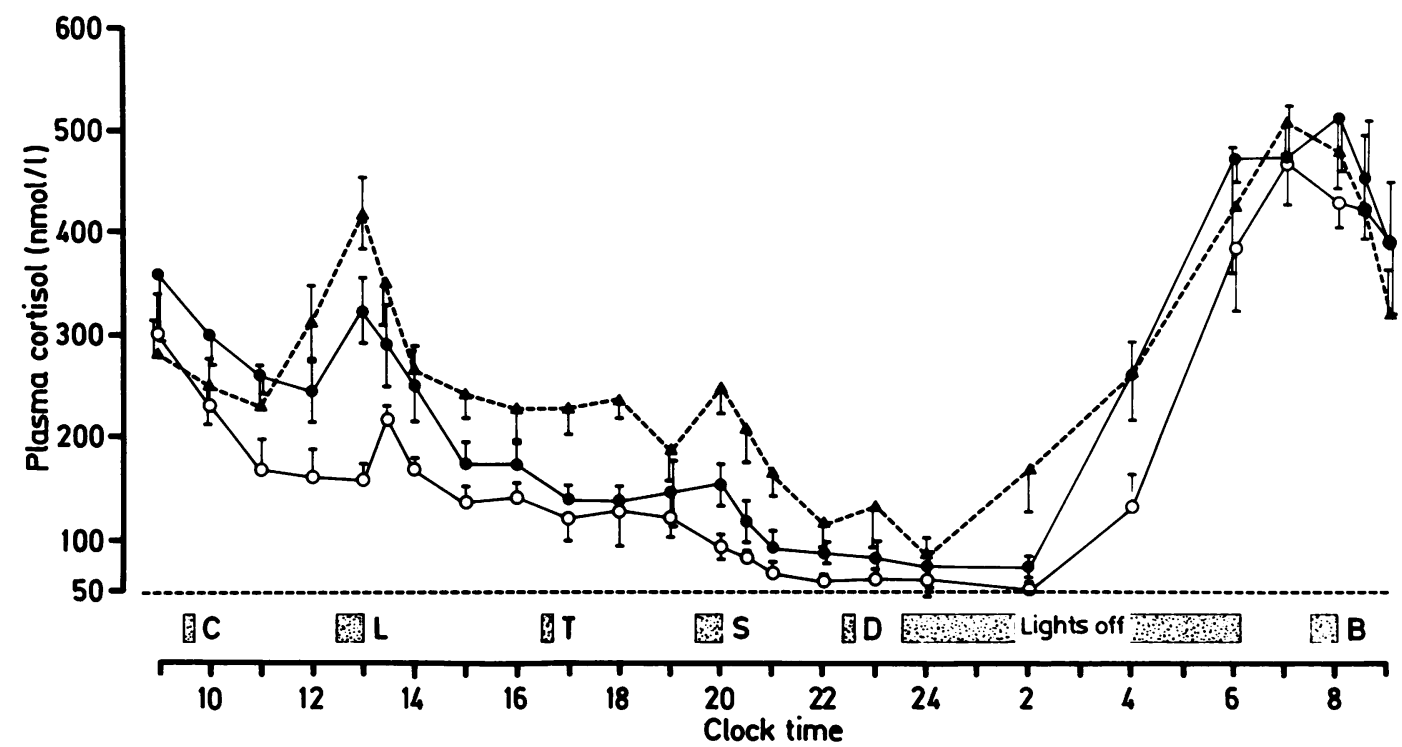

Fig 5 Effects of intravenous infusions of methoxamine (triangles), thymoxamine (open circles), and saline (closed circles) on 24 hour pattern of plasma cortisol in six normal subjects. C, coffee; L, lunch; T, tea; S, supper; D, drink; $B$, breakfast. (Reproduced by permission of the publishers of Clinical Endocrinology, Oxford: Blackwell Scientific Publications.)
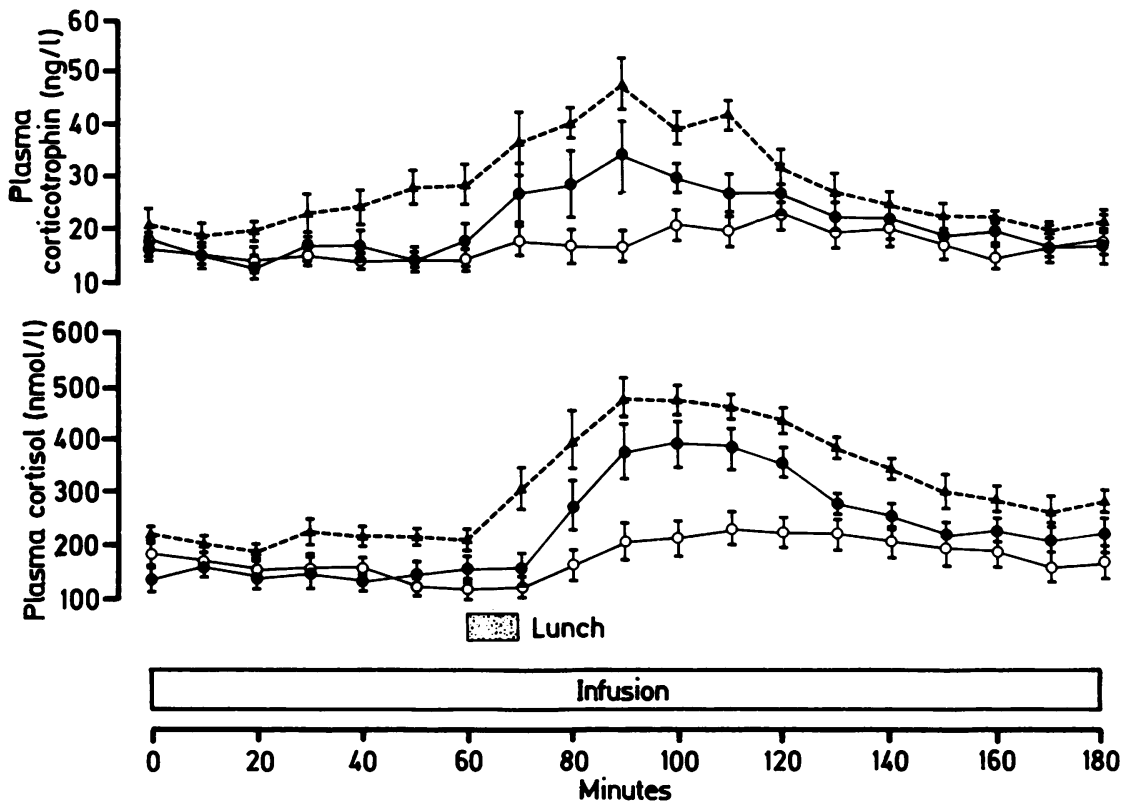

Fig 6 Effects of methoxamine (1 $\mu \mathrm{g} / \mathrm{kg} /$ minute), thymoxamine $(0.15 \mathrm{mg} / \mathrm{kg}$ bolus $+2.5 \mu \mathrm{g} / \mathrm{kg} / \mathrm{minute})$, and saline on $A C T H$ and cortisol responses to food ingestion in six normal subjects. Infusions were given continuously throughout study and lunch was given at 60 minutes. Triangles, methoxamine; closed circles, saline; and open circles, thymoxamine. (Reproduced by permission of the publishers of Clinical Endocrinology, Oxford: Blackwell Scientific Publications.) 

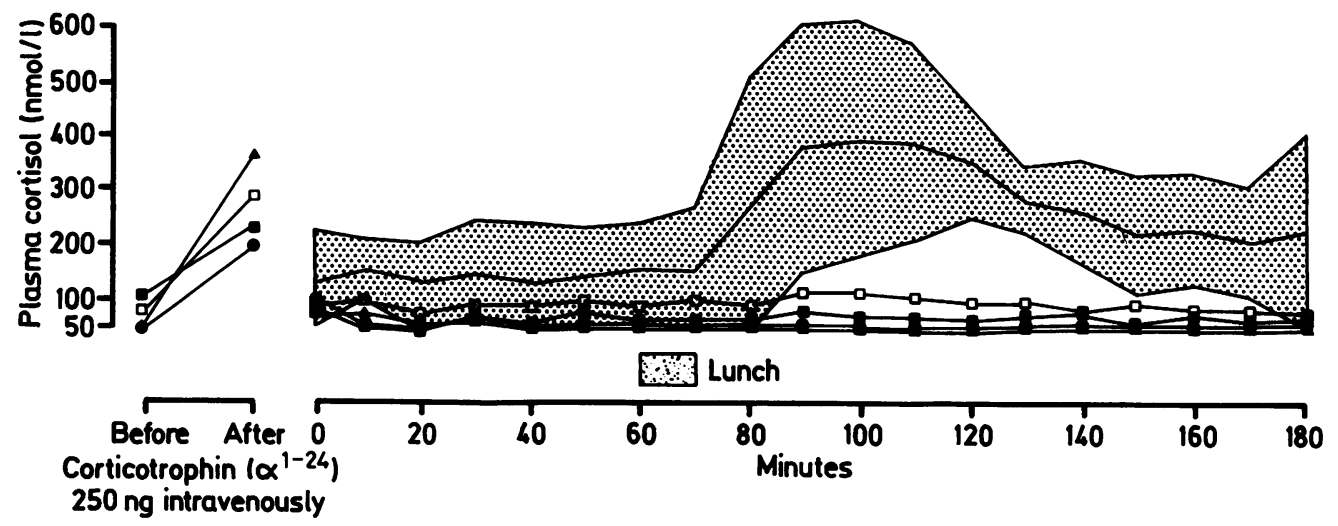

Fig 7 Effect of lunch on plasma cortisol in six normal subjects (shaded area mean $\pm 2 S D$ ) and four patients with pituitary ACTH deficiency and responsive adrenal glands. Left panel shows plasma cortisol responses to physiological dose of ACTH in four patients. (Reproduced by permission of the publishers of Clinical Endocrinology, Oxford: Blackwell Scientific Publications.)

glands were given the same standard meal. There was no ACTH or cortisol response in any of these patients, indicating that the source of the secretion was the pituitary gland (fig 7). ${ }^{93}$ In conclusion, cortisol secretion after the ingestion of food is mediated by central stimulant $\alpha_{1}$ adrenoceptors which modulate the secretion of pituitary ACTH.

\section{THE CORTISOL RESPONSE TO HY POGL YCAEMIA}

Hypoglycaemia is not physiological in man, but several studies have examined the effects of $\alpha$ and $\beta$-adrenoceptor antagonists on the cortisol response to this pharmacological stimulus. Nakai et al ${ }^{61}$ reported that phentolamine blunted the cortisol response to hypoglycaemia induced by insulin, but their findings could not be confirmed by several other groups. ${ }^{96-99}$ It therefore seems at this stage that the HPAA response to hypoglycaemia, like the nocturnal surge of cortisol secretion, is not mediated by $\alpha_{1}$ adrenoceptors.

Nakai et $a l^{61}$ reported that propranolol enhanced the pituitary-adrenal response to hypoglycaemia induced by insulin but their results were not confirmed by other investigators. ${ }^{9798100}$ As described above, we found no stimulant effect of peripheral $\beta$-adrenoceptor activation on ACTH secretion basally or after CRF-41 injection in man. As yet no clear evidence exists for a role of $\beta$-adrenergic mechanisms in the control of ACTH secretion in man. In rats, however, $\beta_{2}$ adrenoceptors stimulate the secretion of the pro-opiocortin-derived peptides from the intermediate lobe, ${ }^{101}$ which is a vestigial organ in man. ${ }^{102}$
The effects of dopaminergic mechanisms on the secretion of ACTH

Dopamine inhibits the secretion of pro-opiocortinderived peptides from the rat intermediate lobe. ${ }^{103}$

The effect may be of physiological relevance, as dopaminergic antagonists stimulate the secretion of the pro-opiocortin-derived peptides in rats and dogs in vivo, ${ }^{104-106}$ suggesting the existence of a tonic inhibitory dopaminergic mechanism. In man dopamine has no effect on the secretion of the proopiocortin-derived peptides by anterior pituitary tissue in vitro. ${ }^{107}$ In healthy subjects dopamine has no important effect on the secretion of ACTH or cortisol under basal conditions ${ }^{53108-110}$ or during hypoglycaemia induced by insulin. ${ }^{108}$ Recently we found that dopamine has no major effect on the ACTH response to CRF-41 (Al-Damluji et al, unpublished observations), but a slight inhibitory action was evident, presumably resulting from the rise of plasma noradrenaline concentrations during the dopamine infusions. This is similar to the inhibitory effect of peripheral adrenoceptor stimulation described above. Dopamine does not cross the blood brain barrier after systemic administration. ${ }^{11}$ Its precursor, 1-dopa, does but may produce ambiguous results as it is converted to noradrenaline and adrenaline as well as dopamine and may interfere with the synthesis of other neurotransmitters such as serotonin. ${ }^{112}$ A useful substitute is bromocriptine, a dopamine agonist that exerts strong central dopaminergic effects when administered systemically. ${ }^{113}$ Metoclopramide is a dopamine antagonist that has prominent central effects when given parenterally. ${ }^{114}$ Neither bromocriptine nor metoclopramide had any 
effect on basal plasma cortisol ${ }^{115}$ in normal subjects, and bromocriptine has no effect on the cortisol response to hypoglycaemia. ${ }^{116}$ On the basis of the available evidence dopaminergic mechanisms do not seem to have a role in the control of ACTH secretion in man.

\section{Conclusion}

An anatomical relation seems to exist between the central adrenergic and noradrenergic systems and the hypothalamo-pituitary adrenal axis. It is possible to show by pharmacological means that $\alpha_{1}$ adrenoceptors stimulate ACTH secretion in man. The site of action of these stimulant $\alpha_{1}$ adrenoceptors is probably within the blood brain barrier, and they presumably act by modulating the secretion of the CRF complex. This mechanism is important in the control of ACTH secretion under some circumstances in man. There is no evidence as yet of important $\beta$-adrenergic or dopaminergic effects on ACTH secretion in man.

\section{References}

1 De Groot J, Harris GW. Hypothalamic control of the anterior pituitary gland and blood lymphocytes. $J$ Physiol 1950;111:335-46.

2 Vale W, Spiess J, Rivier C, Rivier J. Characterization of a 41-residue ovine hypothalamic peptide that stimulates secretion of corticotropin and beta-endorphin. Science 1981;213:1394-7.

3 Swanson LW, Sawchenko PE, Rivier J, Vale W. Organization of ovine corticotropin-releasing factor immunoreactive cells and fibers in the rat brain: An immunohistochemical study. Neuroendocrinology 1983;36:165-86.

4 Bloom FE, Battenberg ELF, Rivier J, Vale W. Corticotropin releasing factor (CRF): immunoreactive neurones and fibers in rat hypothalamus. Regulatory Peptides 1982;4:43-8.

5 Kruseman ACN, Linton EA, Ackland J, Besser GM, Lowry PJ. Heterogeneous immunocytochemical reactivities of oCRF-41-like material in the human hypothalamus, pituitary and gastrointestinal tract. Neuroendocrinology 1984;38:212-6.

6 Gillies G, Linton EA, Lowry PJ. Corticotrophin releasing activity of the new CRF is potentiated several times by vasopressin. Nature 1982;299:355-7.

7 Vogt M. The concentration of sympathin in different parts of the central nervous system under normal conditions and after the administration of drugs. $J$ Physiol 1954;123:451-81.

8 Bertler A, Rosengren E. Occurrence and distribution of catechol amines in brain. Acta Physiologica Scandinavica 1959;47: 350-61.

9 Bertler A. Occurrence and localization of catechol amines in the human brain. Acta Physiologica Scandinavia 1961;51:97-107.

10 Weiner RI, Shryne JE, Gorski RA, Sawyer CH. Changes in the catecholamine content of the rat hypothalamus following deafferentation. Endocrinology 1972;90:867-73.

11 Brownstein MJ, Palkovits M, Tappaz ML, Saavedra JM, Kizer JS. Effect of surgical isolation of the hypothalamus on its neurotransmitter content. Brain Res 1976;117:287-95.

12 Ungerstedt U. Stereotaxic mapping of the monoamine pathways in the rat brain. Acta Physiologica Scandinavica 1971;(suppl 367): 1-48.

13 Anden NE, Dahlstrom A, Fuxe K, Larsson K, Olson L, Ungerstedt $U$. Ascending monoamine neurons to the telencephalon and diencephalon. Acta Physiologica Scandinavica 1966;67:313-26.
14 Lindvall $\mathrm{O}$, Bjorklund $\mathrm{A}$. The organization of the ascending catecholamine systems in the rat brain. Acta Physiologica Scandinavica 1974;(suppl 412):1-48.

15 Palkovits M, Zaborszky L, Feminger A, et al. Noradrenergic innervation of the rat hypothalamus: experimental biochemical and electron microscopic studies. Brain Res 1980;191:161-71.

16 Sawchenko PE, Swanson LW. Central noradrenergic pathways for the integration of hypothalamic neuroendocrine and autonomic responses. Science 1981;214:685-7.

17 Bowden DM, German DC, Poynter WD. An autoradiographic, semistereotaxic mapping of major projections from locus coeruleus and adjacent nuclei in macaca mulatta. Brain Res 1978; 145:257-76.

18 Bjorklund A, Falck B, Hromek F, Owman C, West KA Identification and terminal distribution of the tuberohypophyseal monoamine fibre systems in the rat by means of stereotaxic and microspectrofluorimetric techniques. Brain Res 1970;17:1-23.

19 Nobin A, Bjorklund A. Topography of the monoamine neuron systems in the human brain as revealed in fetuses. Acta Physiologica Scandinavica 1973;(suppl 388):1-40.

20 McNeill TH, Sladek JR. Simultaneous monoamine histofluorescence and neuropeptide immunocytochemistry: II. Correlative distribution of catecholamine varicosities and magnocellular neurosecretory neurons in the rat supraoptic and paraventricular nuclei. Journal of Comparative Neurology 1980;193:1023-33.

21 Sawchenko PE, Swanson LW. The organization of noradrenergic pathways from the brain stem to the paraventricular and supraoptic nuclei in the rat. Brain Research Reviews 1982;4:275-325.

22 Swanson LW, Sawchenko PE, Berod A, Hartman BK, Helle $\mathrm{KB}$, Vanorden DE. An immunohistochemical study of the organization of catecholaminergic cells and terminal fields in the paraventricular and supraoptic nuclei of the hypothalamus. Journal of Comparative Neurology 1981;196: 271-85.

23 Hokfelt T, Fuxe K, Goldstein M, Johansson O. Evidence for adrenaline neurons in the rat brain. Acta Physiologica Scandinavica 1973;89:286-8.

24 Hokfelt $T$, Fuxe $\mathrm{K}$, Goldstein $\mathrm{M}$, Johansson $O$. Immunohistochemical evidence for the existence of adrenaline neurons in the rat brain. Brain Res 1974;66:235-51.

25 Koslow SH, Schlumpf M. Quantitation of adrenaline in rat brain nuclei and areas by mass fragmentography. Nature 1974;251:530-1.

26 Van Der Gugten J, Palkovits M, Wijnen HLJM, Versteeg DHG. Regional distribution of adrenaline in rat brain. Brain Res 1976;107:171-5.

27 Saavedra JM, Palkovits M, Brownstein MJ, Axelrod J. Localisation of phenylethanolamine $\mathrm{N}$-methyl transferase in the rat brain nuclei. Nature 1974;248:695-6.

28 Mezey E, Kiss JZ, Skirboll LR, Goldstein M, Axelrod J. Increase of corticotropin-releasing factor staining in rat paraventricular nucleus neurones by depletion of hypothalamic adrenaline. Nature 1984;310:140-1.

29 Bjorklund A, Lindvall O, Nobin A. Evidence of an incertohypothalamic dopamine neuron system in the rat. Brain Res 1975;89:29-42.

30 Bjorklund A, Falck B, Rosengren E. Monoamines in the pituitary gland of the pig. Life Sci 1967;6:2103-10.

31 Saavedra JM, Palkovits M, Kizer JS, Brownstein M, Zivin JA. Distribution of biogenic amines and related enzymes in the rat pituitary gland. $J$ Neurochem $1975 ; 25: 257-60$.

32 Bjorklund A, Moore RY, Nobin A, Stenevi U. The organization of tubero-hypophyseal and reticulo-infundibular catecholamine neuron systems in the rat brain. Brain Res 1973;51:171-91.

33 Ben-Jonathan N, Oliver C, Weiner HJ, Mical RS, Porter JC. Dopamine in hypophyseal portal plasma of the rat during the 
estrous cycle and throughout pregnancy. Endocrinology 1977;100:452-8.

34 Plotsky PM, Gibbs DM, Neill JD. Liquid chromatographicelectrochemical measurement of dopamine in hypophyseal stalk blood of rats. Endocrinology 1978;102:1887-94.

35 Cramer OM, Parker CR, Porter JC. Secretion of dopamine into hypophyseal portal blood by rats bearing prolactin-secreting tumours or ectopic pituitary glands. Endocrinology 1979;105:636-40.

36 Gudelsky A, Porter JC. Release of newly synthesised dopamine into the hypophyseal portal vasculature of the rat. Endocrinology 1979;104:583-7.

37 Reymond AJ, Porter JC. Hypothalamic secretion of dopamine after inhibition of aromatic 1-amino acid decarboxylase activity. Endocrinology 1982;111:1051-6.

38 Johnston CA, Gibbs DM, Negro-Vilar A. High concentrations of epinephrine derived from a central source and 5-hydroxyindole-3-acetic acid in hypophyseal portal plasma. Endocrinology 1983;113:819-21.

39 Plotsky PM, Bruhn TO, Vale W. Evidence for multifactor regulation of the adrenocorticotropin response to hemodynamic stimuli. Endocrinology 1985;116:633-9.

40 Gibbs DM. Hypothalamic epinephrine is released into hypophyseal portal blood during stress. Brain Res 1985;335:360-4.

41 Leibowitz SF, Jhanwar-Uniyal M, Dvorkin B, Makman MH. Distribution of alpha adrenergic, beta adrenergic and dopaminergic receptors in discrete hypothalamic areas of rat. Brain Res 1982;233:97-114.

42 Petrovic SL, McDonald JK, Snyder GD, McCann SM. Characterization of beta adrenergic receptors in rat brain and pituitary using a new high affinity ligand $\left({ }^{125} \mathrm{I}\right)$ iodocyanopindolol. Brain Res 1983;261:249-59.

43 Crease I, Sibley DR, Leff SE. Agonist interactions with dopamine receptors: focus on radioligand binding studies. Fed Proc 1984;43:2779-84.

44 Recant LH, Hume DM, Forsham PH, Thorn GW. Studies on the effect of epinephrine on the pituitary-adrenocortical system. J Clin Endocrinol 1950;10:187-229.

45 Hunter JD, Bayliss RIS, Steinbeck AW. Effect of adrenaline on adrenocortical secretion. Lancet 1955; i:884-6.

46 Ely RS, Bray PF, Raile RB, Kelley VC. Studies of 17-hydroxycorticosteroids. V. Responses of 17-hydroxycorticosteroids, eosinophils, and glucose to ACTH and epinephrine. J Clin Invest 1954;33:1587-93.

47 Sandberg AA, Nelson DH, Palmer JG, Samuels LT, Tyler FH. The effects of epinephrine on the metabolism of 17-hydroxycorticosteroids in the human. J Clin Endocrinol Metab 1953;13:629-47.

48 Arner B, Hedner P, Karlefors T, Westling H. Haemodynamic changes and adrenal function in man during induced hypoglycaemia. Acta Endocrinol 1963;44:430-42.

49 Vernikos-Danellis J, Marks BH. Epinephrine-induced release of ACTH in normal human subjects: A test of pituitary function. Endocrinology 1962;70:525-31.

50 Vance VK, Shioda Y. Effect of intravenous epinephrine on blood ACTH concentration as measured by steroidogenesis in the hypophysectomised rat. Endocrinology 1964;74:807-8.

51 Muller-Hess R, Geser CA, Jequier E, Felber JP, Vannotti A. Effects of adrenaline on insulin-induced release of $\mathrm{GH}$ and cortisol in man. Acta Endocrinol 1974;75:260-73.

52 Clutter WE, Bier DM, Shah SD, Dryer PE. Epinephrine plasma clearance rates and physiologic thresholds for metabolic and hemodynamic actions in man. J Clin Invest 1980;66:94-101.

53 Wilcox CS, Aminoff MJ, Millar JGB, Keenan J, Kremer M. Circulating levels of corticotrophin and cortisol after infusions of L-Dopa, dopamine and noradrenaline, in man. Clin Endocrinol 1975;4:191-8.

54 Silverberg AD, Shah SD, Haymond MW, Cryer PE. Norepinephrine: hormone and neurotransmitter in man. Am J Physiol 1978;234:E252-6.
55 Besser GM, Butler PWP, Landon J, Rees L. Influence of amphetamines on plasma corticosteroid and growth hormone levels in man. $\mathrm{Br}$ Med $\mathrm{J}$ 1969;iv:528-30.

56 Rees LH, Butler PWP, Gosling C, Besser GM. Adrenergic blockade and the corticosteroid and growth hormone responses to methylamphetamine. Nature 1970;228:565-6.

57 Cohen MR, Nurnberger JI, Pickar D, Gershon E, Bunney WE. Dextroamphetamine infusions in normals result in correlated increases of plasma B-endorphin and cortisol immunoreactivity. Life Sci 1981;29:1243-7.

58 Starke K, Endo T, Taube HD. Relative pre- and postsynaptic potencies of alpha-adrenoceptor agonists in the rabbit, pulmonary artery. Archives of Pharmacology 1975;291:55-78.

59 Drew GM. Effects of $\beta$-adrenoceptor agonists and antagonists on pre- and postsynaptically located $\beta$-adrenoceptors. Eur $J$ Pharmacol 1976;36:313-20.

60 Drew GM. Gower AJ, Marriott AS. Alpha 2 adrenoceptors mediate clonidine-linduced sedation in the rat. Br J Pharmacol 1979;67:133-41.

61 Nakai Y, Imura H, Yoshimi T, Matsukura S. Adrenergic control mechanism for ACTH secretion in man. Acta Endocrinol 1973;74:263-70

62 Al-Damluji S, Perry L, Tomlin S, et al. Alpha-adrenergic stimulation of corticotropin secretion by a specific central mechanism in man. Neuroendocrinology 1987;45:68-76.

63 Karim SMM. Sympathetic beta-receptor blocking action of methoxamine. Br J Pharmacol 1965;24:365-74.

64 Birmingham AT, Szolcsanyi J. Competitive blockade of adrenergic alpha-receptors and histamine receptors by thymoxamine. J Pharm Pharmacol 1965;17:449-58.

65 Al-Damluji S, Grossman A, Turner P, Besser GM. Thymoxamine: lack of antihistaminic effects in clinical doses in man. Br J Clin Pharmacol 1987;24:96-9.

66 Reynolds JEF. The extra pharmacopoeia. 28th ed. London: The Pharmaceutical Press.

67 Weil-Malherbe H, Whitby LG, Axelrod J. The blood-brain barrier for catecholamines in different regions of the brain. In: Kety SS, Elker J, eds. Regional neurochemistry. Oxford:? Pergamon Press, 1961:284-92.

68 Whitby LG, Axelrod J, Weil-Malherbe H. The fate of H3-norepinephrine in animals. Journal of Pharmacology and Experimental Therapeutics 1961;132:193-201.

69 Samorajski T, Marks BH. Localization of tritiated norepinephrine in mouse brain. $J$ Histochem Cytochem 1962;10:392-9.

70 Shimamoto K, Miyahara M. Effect of norepinephrine infusion on plasma vasopressin levels in normal human subjects. $J$ Clin Endocrinol Metab 1976;43:201-4.

71 Krieger HP, Krieger DT. Chemical stimulation of the brain: effect on adrenal corticoid release. Am $J$ Physiol 1970;218:1632-41.

72 Szafarczyk A, Alonsa G, Ixart G, Malaval F, Assenmacher I Diurnal-stimulated and stress-induced ACTH release in rats is mediated by ventral noradrenergic bundle. Am J Physiol 1985;249:E219-26.

73 Weiner RI, Ganong WF. Role of brain monoamines and histamine in regulation of anterior pituitary secretion. Physiol Rev 1978;58:905-76.

74 Tilders FJH, Berkenbosch F, Smelik PG. Adrenergic mechanisms involved in the control of pituitary-adrenal activity in the rat: A $\beta$-adrenergic stimulatory mechanism. Endocrinology 1982;110:114-20.

75 Giguere V, Labrie F. Additive effects of epinephrine and corticotropin releasing factor (CRF) on adrenocorticotropin release in rat anterior pituitary cells. Biochem Biophys Res Commun 1983;110:456-62.

76 Vale W, Vaughan J, Smith M, Yamamoto G, Rivier J, Rivier C. Effects of synthetic ovine corticotropin-releasing factor, glucocorticoids, catecholamines, neurohyophyseal peptides, and other substances on cultured corticotropic cells. Endocrinology 
1983;113:1121-31.

77 Al-Damluji S, Cunnah D, Grossman A, et al. Effect of adrenaline on basal and corticotropin-releasing factor-stimulated ACTH secretion in man. J Endocrinol 1987;112:145-50.

78 Robertson D, Johnston GA, Robertson RM, Nies AS, Shand DG, Oates JA. Comparative assessment of stimuli that release neuronal and adrenomedullary catecholamines in man. Circulation 1979;59:637-43.

79 Grossman A, Bouloux P, Price P, et al. The role of opioid peptides in the hormonal responses to acute exercise in man. Clin Sci 1984;67:483-91.

80 Christensen NJ, Videbaek J. Plasma catecholamines and carbohydrate metabolism in patients with acute myocardial infarction. J Clin Invest 1974;54:278-86.

81 Wortsman J, Frank S, Cryer PE. Adrenomedullary response to maximal stress in humans. Am J Med 1984;77:779-84.

82 Benedict CR, Grahame-Smith DG. Plasma noradrenaline and adrenaline concentrations and dopamine-beta-hydroxylase activity in patients with shock due to septicaemia, trauma and haemorrhage. $Q J$ Med 1978;185:1-20.

83 Milsom SR, Donald RA, Espiner EA, Nicholls MG, Livesey JH. The effect of peripheral catecholamine concentrations on the pituitary-adrenal response to corticotrophin releasing factor in man. Clin Endocrinol 1986;25:241-6.

84 Lanes R, Herrera A, Palacios A, Moncada G. Decreased secretion of cortisol and ACTH after oral clonidine administration in normal adults. Metabolism 1983;32:568-70.

85 Baranowska B, Misiorowski W, Dorobek W, Witkowski M, Snochowska H, Soszynski P. The opposite effect of naloxone and clonidine on GH, TSH and LH release in healthy subjects. Neuroendocrinology Letters 1985;7:297-303.

86 Farsang C, Vajda L, Kapocsi J, et al. Diurnal rhythm of beta endorphin in normotensive and hypertensive patients: the effect of clonidine. J Clin Endocrinol Metab 1983;56:865-7.

87 Grossman A, Weerasuriya K, Al-Damluji S, Turner P, Besser GM. Alpha 2 adrenoceptors stimulate growth hormone secretion but have no acute effects on plasma cortisol under basal conditions. Hormone Research 1987;25:65-71.

88 Gann DS, Egdahl RH. Responses of adrenal corticosteroid secretion to hypotension and hypovolemia. J Clin Invest 1965;44:1-7.

89 Wood CE, Shinsako J, Keil LC, Ramsay DJ, Dallman MF. Hormonal and hemodynamic responses to $15 \mathrm{ml} / \mathrm{kg}$ hemorrhage in conscious dogs: responses correlate to body temperature. Proc Soc Exp Biol Med 1981;167:15-9.

90 Al-Damluji S, Cunnah D, Perry L, Grossman A, Besser GM. The effect of alpha adrenergic manipulation on the 24 hour pattern of cortisol secretion in man. Clin Endocrinol 1987;26:61-6.

91 Brandenberger G, Follenius M. Variations diurnes de la cortisolemie, de la glycemie et du cortisol libre urinaire chez l'homme au repos. J Physiol (Paris) 1973;66:271-82.

92 Myers RD, McCaleb ML. Feeding: satiety signal from intestine triggers brain's noradrenergic mechanism. Science 1980;209: 1035-7.

93 Al-Damluji S, Iveson T, Thomas JM, Pendlebury DJ, Rees LH, Besser GM. Food induced cortisol secretion is mediated by central alpha-1 adrenoceptor modulation of pituitary ACTH secretion. Clin Endocrinol 1987;26:629-36.

94 Larsson LI. Corticotropin-like peptides in central nerves and in endocrine cells of gut and pancreas. Lancet 1977;ii:1321-23.

95 Larsson LI. Radioimmunochemical characterization of ACTH-like peptides in antropyloric mucosa. Life Sci 1979;25:1565-70.

96 Nakagawa K, Horiuchi $Y$, Mashimo K. Further studies on the relation between growth hormone and corticotrophin secretion in insulin-induced hypoglycemia. J Clin Endocrinol 1971;32: 188-91.

97 Jacobs SJ, Gewirtz G, Krieger DT. Pituitary-adrenal response to $\alpha$ - and $\beta$-adrenergic blocking agents. Fed Proc 1973;32:295

98 Rizza RA, Cryer PE, Gerich JE. Role of glucagon, catecholamines and growth hormone in human glucose counter- regulation. J Clin Invest 1979;64:62-71.

99 Cuneo RC, Livesey JH, Nicholls MG, Espiner EA, Donald RA. Effect of alpha-1 adrenergic blockade on the hormonal response to hypoglycaemic stress in normal man. Clin Endocrinol 1987;26:1-8.

100 Abramson EA, Arky RA, Woeber KA. Effects of propranolol on the hormonal and metabolic responses to insulin-induced hypoglycaemia. Lancet 1966;ii:1386-9.

101 Cote T, Munemura M, Eskay RL, Kebabian JW, Long R. Biochemical identification of the $\beta$-adrenoceptor and evidence for the involvement of an adenosine $3^{\prime}, 5^{\prime}$-monophosphate system in the $\beta$-adrenergically induced release of -melanocytestimulating hormone in the intermediate lobe of the rat pituitary gland. Endocrinology 1980;107:108-16.

102 Rasmussen AT. The morphology of pars intermedia of the human hypophysis. Endocrinology 1928;12:129-50.

103 Vermes I, Mulder GH, Smelik PG, Tilders FJH. Differential control of beta endorphin/beta lipotropin secretion from anterior and intermediate lobes of the rat pituitary gland in vitro. Life Sci 1980;27:1761-8.

104 Farah JM Jr, Malcolm D, Mueller GP. Dopaminergic inhibition of pituitary $\beta$-endorphin-like immunoreactivity secretion in the rat. Endocrinology 1982;110:657-9.

105 Sharp B, Ross R, Levin E, Sowers J. Dopamine regulates canine plasma $\beta$-endorphin-immunoreactivity levels. Endocrinology 1982;110:1828-30.

106 Sharp B, Kasson B, Marshak D, et al. Domperidone elevates rat plasma $\beta$-endorphin-immunoreactivity when administered peripherally but not intracerebroventricularly. Life Sci 1982;31:981-5.

107 Gibbs DM, Stewart RD, Liu JH, Vale W, Rivier J, Yen SSC Effects of synthetic corticotropin-releasing factor and dopamine on the release of immunoreactive beta-endorphin/beta-lipotropin and alpha-melanocyte-stimulating hormone from human fetal pituitaries in vitro. $J$ Clin Endocrinol Metab 1982;55:1149-52.

108 Leebaw WF, Lee LA, Woolf PD. Dopamine affects basal and augmented pituitary hormone secretion. J Clin Endocrinol Metab 1978;47:480-7.

109 Levinson PD, Goldstein DS, Munson PJ, Gill JR, Keiser HR. Endocrine, renal, and hemodynamic responses to graded dopamine infusions in normal men. J Clin Endocrinol Metab 1985;60:821-6.

110 Connell JMC, Kenyon CJ, Ball SG, Davies DL, Fraser R. Dopamine effects on adrenocorticotrophin-stimulated aldosterone, cortisol, corticosterone and 11-deoxycorticosteroid concentrations in sodium-replete and sodium-deplete man. $J$ Endocrinol 1986;109:339-44.

111 Oldenorf WH. Brain uptake of radiolabelled amino acids, amines, and hexoses after arterial injection. Am $J$ Physiol 1971;221:1629-39.

112 Bertler A, Rosengren E. On the distribution in brain of monoamines and of enzymes responsible for their formation. Experientia 1959;15:382-4.

113 Corrodi H, Fuxe K, Hokfelt T, Lidbrink P, Ungerstedt U. Effect of ergot drugs on central catecholamine neurons: evidence for a stimulation of central dopamine neurons. J Pharm Pharmacol 1973;25:409-11.

114 Peringer E, Jenner P, Marsden CD. Effect of metoclopramide on turnover of brain dopamine, noradrenaline and 5-hydroxytryptamine. J Pharm Pharmacol 1975;27:442-4.

115 Carey RM, Thorner MO, Ortt EM. Effects of metoclopramide and bromocryptine on the renin-angiotensin-adlosterone system in man. J Clin Invest 1979;63:727-35.

116 del Pozo E, Friesen H, Burmeister P. Endocrine profile of a specific prolactin inhibitor: Br-Ergocryptine (CB 154) Schweiz Med Wochenschr 1973;103:847-8.

Requests for reprints to: Dr Al-Damluji, Department of Endocrinology, St Bartholomew's Hospital, West Smithfield, London EC1A 7BE, England. 